\title{
A Superficial Varicose Vein Mimicking Soft Tissue Infection on 99mTc Human Polyclonal Immune Globulin Scintigraphy: Original Image
}

\author{
99mTc İnsan Poliklonal İmmün Globulin \\ Sintigrafisinde Yumuşak Doku Enfeksiyonunu \\ Taklit Eden Süperfisyal Varikoz Ven
}

Muhammet AȘIK, MD,

Melih Engin ERKAN, MD,

Ayşe YILMAZ, MD, ${ }^{\text {a }}$

Erdinç IZGi, MD, ${ }^{\text {a }}$

Ömer YAZGAN, MD, ${ }^{b}$

Ömer ÖNBAȘ, MD,

Mustafa YILDIRIM, MD, a

Ahmet Semih DOĞAN, MD

\section{Departments of}

Nuclear Medicine

${ }^{\text {'Radiology, }}$

Düzce University Faculty of Medicine,

Düzce

Geliş Tarihi/Received: 25.10 .2010 Kabul Tarihi/Accepted: 25.03.2011

Yazıșma Adresi/Correspondence: Melih Engin ERKAN, MD

Düzce University Faculty of Medicine, Department of Nuclear Medicine, Düzce, TÜRKIYE/TURKEY

melihenginerkan@yahoo.com
ABSTRACT 99mTechnetium human polyclonal immune globulin (99mTc-HIG) is a useful radiopharmaceutical in diagnosing infection. A 61-year-old woman with painful left knee prosthesis was investigated for septic loosening. In addition to prosthetic infection which presented as diffusely increased uptake surrounding left knee, a focally increased uptake below the medial side of right knee was noticed on $99 \mathrm{mTc}-\mathrm{HIG}$ images. Although background and vascular activity were diminished at 24 hours after injection, the area of activity below the right knee was more apparent. We assumed this finding was due to soft tissue infection, however, a superficial varicose vein was shown by Doppler ultrasound. We conclude that varicose veins may be misinterpreted as a site of infection and thus may cause false positive results on $99 \mathrm{mTc}-\mathrm{HIG}$ scintigraphy.

Key Words: Prosthesis failure; radionuclide imaging; varicose veins; soft tissue infections

ÖZET 99mTc-HIG, enfeksiyon tanısında yararlı bir radyofarmasötiktir. Ağrılı sol diz protezi olan 61 yaşındaki kadın hasta septik ayrilma nedeniyle araştırıldı. 99mTc-HIG görüntülemesinde sol diz çevresinde yaygın artmış tutulum ile kendini gösteren prostetik enfeksiyona ek olarak, sağ diz medial kesimin alt kısmında fokal artmış tutulum tespit edildi. Enjeksiyondan 24 saat sonra arka plan ve vasküler aktiviteler azalmış olsa da sağ diz altındaki bölgenin aktivitesi daha belirgin hale gelmişti. Bu bulgunun yumuşak doku enfeksiyonuna bağlı olduğunu varsaydık ancak Doppler ultrasonu ile süperfisyal bir varikoz ven görüntülendi. Varikoz venlerin, enfeksiyon yeri olarak yanlış yorumlanabileceği ve bu nedenle $99 \mathrm{mTc}$-HIG sintigrafisinde yanlış pozitif sonuçlara neden olabileceği sonucuna vardık.

Anahtar Kelimeler: Protez yetmezliği; radyonüklid görüntüleme; variköz venler; yumuşak doku enfeksiyonları

Turkiye Klinikleri J Med Sci 2011;31(3):763-5

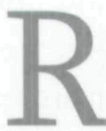
adionuclide imaging methods are the current imaging modalities in the evaluation of suspected joint replacement infection. ${ }^{1} 99 \mathrm{~m}$ Technetium human polyclonal immune globulin ( $99 \mathrm{mTc}-\mathrm{HIG}$ ) is a useful approach to evaluate infection sites. It is widely available in kit form and can be used with simple intravenous injection. This agent accumulates in infectious and inflammatory foci by non-specific extravasations, facilitated by locally enhanced vascular permeability. ${ }^{2}$ Unlike monoclonal antibodies, HIG does not induce antibody reactions. ${ }^{3}$ 
To avoid unnecessary treatment, it is extremely important to distinguish false-positive reasons of $99 \mathrm{mTc}$-HIG scintigraphy properly. False positive uptake may be excluded by careful examination and history of the patients. We present an interesting image of varicose vein, which mimics soft tissue infection on $99 \mathrm{mTc}$-HIG scintigraphy.

A 61-year old woman with painful left knee prosthesis was investigated for differential diagnosis of loosening from prosthesis infection. Diffusely increased uptake surrounding left knee prosthesis was shown on $99 \mathrm{mTc}^{\mathrm{T}} \mathrm{HIG}^{4,5}$ images,

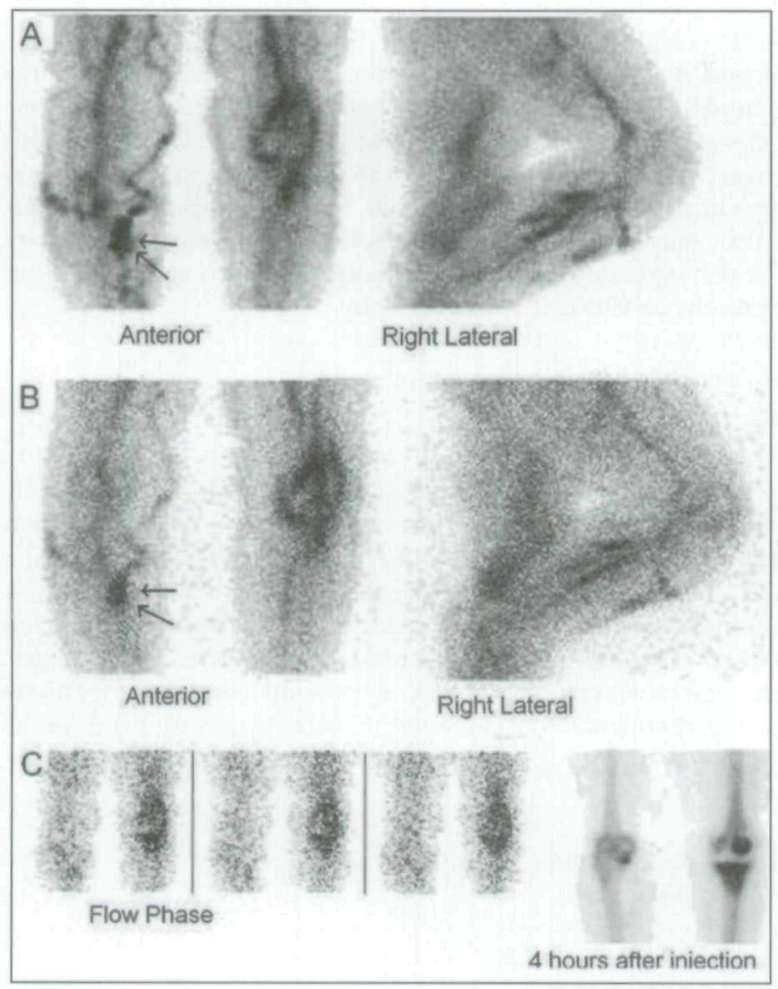

FIGURE 1: Diffusely increased uptake surrounding left knee prosthesis was shown on $99 \mathrm{mTC}-\mathrm{HIG}$ images.A,B 99mTc-MDP study also supports the diagnosis of prosthetic infection.C Furthermore, a focal area of increased uptake is noted below the medial side of right knee (arrows) at three hours after injection on anterior and right lateral images. A Although background and vascular activity are decreased in time, uptake below the right knee becomes more apparent (arrows) at 24 hours after injection.B In the area where an increased focal activity is observed with $99 \mathrm{mTc}-\mathrm{HIG}$ imaging at the right leg, a mildly increased focal perfusion was also noted in the flow phase of the bone scan.C

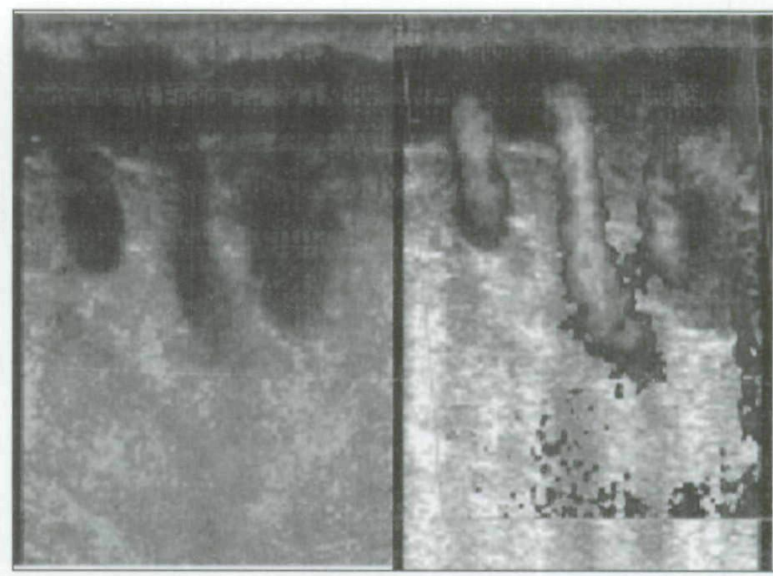

FIGURE 2: A superficial varicose vein is shown by Doppler ultrasound below the right knee corresponding to the site of focal increased persistent abnormal uptake on the $99 \mathrm{mTc}-\mathrm{HIG}$ study.

suggestive for diagnosis of infection (Figure 1). Furthermore, a focal area of increased uptake was noted below the medial side of right knee at three hours after injection on anterior and right lateral images. Although background and vascular activity were decreased in time, uptake below the right knee became more apparent at 24 hours after injection. Since $99 \mathrm{mTc}-\mathrm{HIG}$ has higher sensitivity to diagnose infection at 24 hours; ${ }^{6}$ we interpreted this finding as a manifestation of soft tissue infection. A superficial varicose vein was shown by Doppler ultrasound ${ }^{7-9}$ below the right knee, corresponding to the site of focal increased persistent abnormal uptake on the $99 \mathrm{mTc}-\mathrm{HIG}$ study (Figure 2).

False positive results in $99 \mathrm{mTc}$-HIG images may be obtained in the musculoskeletal conditions such as synovial tumors, Charcot joint, subacromial impingement and adhesive capsulitis. ${ }^{10,11}$ Uptake of $99 \mathrm{mTc}-\mathrm{HIG}$ was reported in a number of benign and malignant soft tissue tumors such as hemangioma and lymphoma. ${ }^{12-14} \mathrm{~A}$ malignant histiocytoma of the bone was also reported. ${ }^{15}$ In the current images, we conclude that varicose veins can also be misinterpreted as a focus of infection and potentially may cause false positive results in 99 mTc-HIG scintigraphy. ${ }^{16}$ 
1. Love C, Tomas MB, Marwin SE, Pugliese PV, Palestro CJ. Role of nuclear medicine in diagnosis of the infected joint replacement. Radiographics 2001;21(5):1229-38.

2. Machens HG, Pallua N, Becker M, Mailaender $P$, Schaller E, Brenner $P$, et al. Technetium-99m human immunoglobulin ( $\mathrm{HIG}$ ): a new substance for scintigraphic detection of bone and joint infections. Microsurgery 1996;17(5): 272-7.

3. Oyen WJ, van Horn JR, Claessens RA, Slooff $\mathrm{TJ}$, van der Meer JW, Corstens FH. Diagnosis of bone, joint, and joint prosthesis infections with In-111-labeled nonspecific human immunoglobulin G scintigraphy. Radiology 1992; 182(1):195-9.

4. Unal SN, Birinci H, Baktiroğlu S, Cantez S. Comparison of Tc-99m methylene diphosphonate, Tc-99m human immune globulin, and Tc-99m-labeled white blood cell scintigraphy in the diabetic foot. Clin Nucl Med 2001;26 (12):1016-21.

5. Özdemir A, Özdemir H, Güngör F. [Radionuclide scanning in osteomyelitis]. Turkiye Klinikleri J Med Sci 1997:17(2):106-10.

6. Palermo F, Boccaletto F, Paolin A, Carniato A, Zoli P, Giusto F, et al. Comparison of tech-

\section{REFERENCES}

netium-99m-MDP, technetium-99m-WBC and technetium-99m-HIG in musculoskeletal inflammation. J Nucl Med 1998;39(3):516-21.

7. Wilson DJ. Soft tissue and joint infection. Eur Radiol 2004;14(Suppl 3):E64-71.

8. Uncu H. [Following varicose vein surgery, should elastic compression bandages or graduated compression stockings be preferred?]. Turkiye Klinikleri J Med Sci 2009; 29(1):1349

9. Gaitini D, Torem S, Pery M, Kaftori JK. Image-directed Doppler ultrasound in the diagnosis of lower-limb venous insufficiency. J Clin Ultrasound 1994;22(5):291-7.

10. Jiménez-Heffernan A, Villanueva JL, Moral A, Rebollo A, González FM, Ureña M, et al. Detection of inflammation/infection with human polyclonal immunoglobulin $\mathrm{G}$ labelled with 99Tcm. Br J Radiol 1994;67(800):770-4

11. Clunie GP, Bomanji J, Renton P, Edwards JC, Ell PJ. Technetium-99m human immunoglobulin imaging in patients with subacromial impingement or adhesive capsulitis. Clin Rheumatol 1998;17(5):419-21.

12. Arka A, Aktolun C, Gooden C, Epenetos A, Papadimitriou A. Tc-99m-labeled nonspecific polyclonal human immunoglobulin $\mathrm{G}$ is taken up by malignant tumors. Clin Nucl Med 1994;19(8):708-12.

13. Küçük NO, Aras G, Soylu A, Ozcan M, Ibis E, Dinçol D. Value of combined $67 \mathrm{Ga}$ and 99Tc(m)-human immunoglobulin $\mathrm{G}$ wholebody scanning in malignant lymphoma. Nucl Med Commun 2001;22(3):325-9.

14. Oyen WJ, Claessens RA, van Horn JR, van der Meer JW, Corstens FH. Scintigraphic detection of bone and joint infections with indium-111-labeled nonspecific polyclonal human immunoglobulin G. J Nucl Med 1990;31(4): 403-12.

15. Machens HG, Pallua N, Becker M, Mailaender $P$, Schaller $E$, Brenner $P$, et al. Technetium-99m human immunoglobulin (HIG): a new substance for scintigraphic detection of bone and joint infections. Microsurgery 1996;17(5): 272-7.

16. Arndt JW, van der Sluys Veer A, Blok D, Griffioen $G$, Verspaget HW, Peña AS, et al. A prospective comparison of $99 \mathrm{mTc}$-labeled polyclonal human immunoglobulin and $111 \mathrm{ln}$ granulocytes for localization of inflammatory bowel disease. Acta Radiol 1992;33(2):1404. 
Copyright of Turkiye Klinikleri Journal of Medical Sciences is the property of Ortadogh Reklam Tanitim ve Yayincilik Turizm Egitim Insaat Sanayi ve Ticaret A.S. and its content may not be copied or emailed to multiple sites or posted to a listserv without the copyright holder's express written permission. However, users may print, download, or email articles for individual use. 